\title{
Afterword: the utopianisation of bureaucracy
}

Utopia, from the ancient Greek "ou-topos" ("not a place" or "nowhere"), quite literally refer to a place that is not there. Perhaps this emphasis on utopia as place is most starkly present in Thomas More's 1516 Utopia which was an island. Bureaucracy, a combination of the French word bureau - desk or office - and the Greek word kratos - rule, also originated as a form of rule or political power that is embedded in place - a desk; an office. These two types of non-places have, up till now, been kept largely separate. The Weberian disenchantedness and the "iron cage of modernity" that is most commonly associated with bureaucracy are normally considered a far cry from the desirability implicit in nonplace places and states of being that are utopias. In this act of putting utopias in conversation with bureaucracy and, in fact, considering utopianisation simultaneously a process and an ideal that forms the foundation of international organisations, this collection makes a series of intellectual manoeuvres that I briefly touch upon as a focus on scale (the international/national/local); bureaucratisation and utopianisation as processes rather than states-of-(non)being; methodological hooks; imaginaries of bureaucracy; and the value of comparison.

Let us begin, however, by considering the central question that this issue poses for us: what happens when, instead of structural critiques of the failures/shortcomings/violence of bureaucracy, we take seriously the utopic ideals that are enshrined in many of them?

Utopias are imagined, desired spaces - normally of the future though this temporality can and does vary. In the international organisations studied here, there is a projection into building better futures, but also a care for the present. Beyond the significance of time and place as well as the desirable qualities of these time-spaces, I think of utopias, following Gordon, Tilley, and Prakash, as "markers for conditions of possibility" (2011: 4). What do utopias make imaginable, what sorts of possibilities do they allow to be 
conjured up? As an anthropologist, it is this imaginativeness and sense of possibility carried by utopian projects, rooted in specific times and places, that I find compelling. Utopias don't exist - or do not not-exist - outside of a relationship with something. The international organisations studied here are attempts to enact and bring into being utopias in relation to human rights (Babul), humanitarianism (Billaud, Mora), peace and co-operation (Cowan), community participation and heritage (Bortolotto et al), and world justice (Halme-Tuomisaari).

These are projects of reform and emancipation: ideals rooted in internationalist beliefs in justice and equality. They are enacted through sprawling bureaucracies spread around the world with dizzying organisational structures, rules, moral codes, unique political-economic resources, and material infrastructures. In the spirit of this collection, I want to think more about utopianism and bureaucratic instruments via a small digression to India and a brief rumination of my own on what I study as 'techno-utopias'. What happens to our understanding of both utopias and bureaucracy when we add technology to the mix? By technology I am referring, firstly, to technology in its colloquial sense - the manner in which people speak of technology and discuss, for instance, new technologies like a smart phone. Furthermore technology, as the word's etymology reminds us, is both knowledge and artifacts. Thus, the technology of an ID that forms the basis for enrolment in a welfare programme in India is both a sense of the card - its papery feel, photograph, columns, its affective charge - as well as a knowledge of the forms of action it allows - the things that allow for welfare to be enacted bureaucratically that might include, for instance, the checking of wages paid against official accounts, the numbers of days worked, the tallying with muster rolls, the building up of evidence of corruption by officials, and so forth. In brief, I use techno-utopia to focus attention on the utopianism of identification - its conditions of possibility and imagination: what worlds of perfect identifiability and knowledge it is aiming at or hoping to bring into being, as well as the technologies through which this utopia of identifiability is brought into being. 
Techno-utopias are useful in and of themselves for getting at the rationality of certain bureaucratic actions and process. But to trace how this utopianism has shifted over time in different bureaucratic projects also gleans certain insights, which I briefly sketch out here through a focus on three distinct IDs, each with a distinctive material presence (and, in the case of the last of the three, material absence).

\section{The Stain, the Card, and the Number}

The first is a stain, more precisely the inedible ink mark that is utilised during elections in India. This is a simple ink, with small amounts of silver nitrate which reacts to light, to mark voters' hands. The ink is manufactured by Mysore Paints and Varnish, has been used in every local and national Indian election, as well as in key elections across the world, including in Iraq and Afghanistan. More than six billion fingers worldwide have been inked over the decades, according to Mysore paints and varnish. In India, the cuticle and nail of the index finger is marked. The recipe for the electoral ink remains a closely guarded secret. In the 2014 general election alone, Mysore Paints and Varnish Ltd had sold 22,000 litres of ink to India's election commission.

The basic point of the election stain is to prevent voter fraud by disallowing repeat voting. Given the vast electorate, this simple stain serves to provide a particular form of an identity - as a voter in this key democratic ritual. More critical than the many selfies that voters now take with the stain, it allows the state to know - with a simple but reassuring certainty -- that the voter has become ineligible to cast their ballot again. Of the three IDs I discuss here, this one - with its material, visual, and administrative simplicity remains one that is perhaps the most foolproof. I want to underline the fact that its raison d'etre is that the voter does not dupe the state or the process of democratic electioneering by voting more than once. Thus, this ID is not so much a symbol of having participated in a core democratic ritual as 
much as it is a quick visual signifier that protects the state itself from identification theft or fraud.

From an ID that is aimed at preventing the democratic principle of one person, one vote being subverted by voter fraud, let me now turn to an ID that has been developed to protect citizens against fraud by the state. This ID forms the cornerstone of the implementation of a welfare scheme called the National Rural Employment Guarantee Act (NREGA) in India that I studied in detail in my earlier work (Mathur 2016). Described by the NREGA operational guidelines issued by the government of India as "a critical legal document, which also helps to ensure transparency and protect labourers against fraud" (GoI 2008: 22). The fundamental purpose of the job card is to allow the labourer to verify what the state claims it has officially paid him/her. Thus, this document contains a photograph of the registered household; it also contains the core details of number of days and hours worked for the NREGS as well as wages earned. Under previous public works programmes such as the SGRY and the National Food for Work Programme (NFFWP) no such document existed that would allow for an independent verification of government records. In those schemes the labourers wages were tabulated and paid from the kachha (temporary) muster roll. The kachha muster roll was then converted into a pukka one by the local state officials/contractors hired to oversee the work, and in the process fake entries were made that allowed money to be pulled out. The labourers had no way of ascertaining what figures were written on the pukka muster roll and, therefore, could never protest against being paid less than they were entitled to. This is why activist organisations stress the fact of seeing government records in order to establish the 'truth' of the state. The Mazdoor Kisan Shakti Sangathan (Workers' and Farmers' Power Union) or MKSS, a prominent Rajasthan based activist organization that lobbied extensively for the RTI and NREGA, pithily sums up this belief in its slogan: 'jaanne ka adhikar, jeene ka adhikar' (the right to information, the right to live). 
With the entry of the job card, it is the first time in the history of rural employment programmes that the labourers themselves hold onto a record that contains information that ought to correspond precisely with the state's version of events. Hence, all monitoring of the NREGS at the level of the village centred upon scrutiny of the job cards. Entries in job cards are read against the official muster rolls to see whether any discrepancies in accounts exist. It is through an examination of these documents, especially the job card that the operations of the state are believed to have been made transparent. The job card laying bare the workings of the state is, of course, an ideal type. It embodies not only the state's purported aim of introducing transparency into its workings but, also, the desire to condition a regulatory sameness in its operations across the length and breadth of India. In practice, the job card is subjected to a variety of different manipulations that disallow, to a large extent, both these objectives.

I have written about the use of job cards in NREGA in greater detail elsewhere, but let me restate that the core rationality of the job card - its techno-utopic impulse so to say - came from a desire to render the state's functioning transparent. It is aimed at preventing state agents from "eating up" welfare funds or from what we term "corruption". The desire for a gleaming new transparent state has been taken to its techno-utopic pinnacle with the Aadhar or a biometric-based ID termed recently introduced in India. As its famous champion the entrepreneur-turned-bureaucrat Nandan Nilekani is fond of saying, "Aadhaar is a number, not a card". I am going to confine my observations to the techno-utopian fantasy of Aadhar here and not how it is being realised in practice. The unique identification number or UID of Aadhaar is a twelve digit number that will be linked to all documents (passports, driving licenses, ration cards, voter ids, etc.) and databases (bank accounts, employment details, welfare provision lists, etc.); henceforth all interactions between the state and its subjects are conceptualised as taking place via this new form of identification. The UID is considered foolproof as it is to be attached to an individual's biometric details: a photograph, fingerprints, and iris scans. Tied to the very body of an 
individual, possessing no material presence, and operable through allegedly unmanipulable softwares, it is supposed to block 'corrupt' transactions on the part of the state functionary and fraud on the part of the citizen. Through the incorruptible virtuality of this number, the mission of transparency in all contact between the state and its wholly identifiable individualised subjects shall, it is believed, be achieved.

Aadhar has generated a complex debate, with opinions made for and against it. Enormous financial costs (estimates range from US $\$ 6$ to $\$ 32.55$ billion), the complexity of the technology required, the danger of loss/abuse of data and privacy, and the potential for the development of an Orwellian Big Brother state are just some of the controversies dogging this grand state project. Yet, the project has continued to flourish on the publicly declared premise that it will fashion a transparent regime of governance: that it is a revolutionary, technological fix, which will address the hitherto unwieldy management of the colossal Indian state. As such, it bears testimony to a utopian thinking, which Mckean has described as "reflections on highly desirable and hoped for social and political circumstances that include no necessary reference to the means, costs, or feasibility of achieving them from our present condition" (2016:1).

More than any of the other three IDs discussed above, Aadhar exemplifies techno-utopianism at its most literal: a world in which it is a machine that does the labour of recognition and, because it is a machine/putatively cutting-edge technology, it is more efficient and incorruptible than humans or flimsy, manipulable substances like paper or cardboard. The adjacency of utopia/dystopia has been noted by many - be it in novels like 1984 or in the writings of Ursula Le Guin or in histories of spectacular modernist experimentations. Perhaps, then, it is no co-incidence that it is Aadhar, enmeshed as it is within the fantasy of a near-future techno-utopia, that possesses the capacity to swiftly transmogrify into a dystopic present. 


\section{The International}

This digression into techno-utopianism and IDs in India is meant to open up certain questions that this issue provokes. The first is the claim - fully justified - that there is something specific to international organisations that might make them more amenable to the grounding of utopias. Indeed, the utopic foundations of the bureaucracies studied here - from the League of Nations to the ICRC to the UN Human Rights Committee- are front and centre. Given the objectives and founding rationales of these organisations, it is safe to assume that the agents who people them are similarly carrying feelings of pursuing an ideal as Cowan (this issue) would have it or, as the sharp contextualisation of Babul's work on human rights in Turkey shows, are 'radical once more'. Then there is the literality of the utopian projects that are not rooted in place per se but travel widely such as Billaud's movement from Geneva to the Democratic Republic of Congo (DRC) or are defined by their nowhere-ness such as the putative black hole of a partially realised state in Mora's work with EULEX. What also makes them utopic is their orientation to time that can move back and forth through time in peculiarly fascinating ways. For instance, Halme-Tuomisaari's study of the UN Human Rights Committee's quest to translate a vision of world justice into practice - through the operations of international law and the production of documents of all sorts - harks back to the 1940s. On the other hand, Babul's bureaucrats and human rights workers are looking to a period in the future related to $\mathrm{EU}$ accession and state liberalisation.

Bortolotto et al work simultaneously in the past - with notions of heritage and the future, with the aim of preserving into the future that which is valuable from the past.

A future desired state of being or a present that is intent on fixing wrongdoing/executing morally important visions, are central to the utopianism of these international bureaucracies. While there is no doubting that the work of international human rights organisations or the League of Nations throws utopianism into sharp relief, I wonder whether we cannot 
extend this approach to the study of state bureaucracies or localised, smaller bureaucratic-like entities such as NGOs too? While much of the emergent ethnographic literature on bureaucracy has been focused on state bureaucracies, the utopianism - in its idealistic sense at the very least if not in the literal one too - is very much in evidence there, as well. For instance, we can see it in the modernist utopia of building a new city of Islamabad (Hull 2012) or governing HIV-AIDS programmes in Pakistan (Qureshi 2017); the workings of the developmental state (Gupta 2012, Mathur 2016) or projects of urban renewal and infrastructure in India (Ghertner 2015, Bear 2015), just to give a few examples from South Asia. Do we need to gesture to the overtly utopic international arena or can we not seek utopianism at the scale of the state or the region too? My suggestion would be that we can, but that move hasn't been made till quite recently. And this move - to centre the utopic contract between state and citizen in ethnographic work - hasn't been highlighted in the manner in which this special issue on the bureaucratisation of utopias via international organisations undertakes so effectively. Perhaps, then, one way to read this collection as a call-to-arms to undertake ethnographic research into bureaucratic organisations at several scales - the international, local, national - keeping in mind that even though the utopian ideals are perhaps most clearly articulated in the kinds of international organisations studied here, we can re-see other bureaucracies as also invested in similar politico-ethical endeavours. This question of utopia and bureaucracy as well as types of utopias and bureaucracies returns me to a critical question of method.

To describe the inner world and workings of bureaucracies isn't the easiest task. There are questions of access, ethics, method, voice, positionality, narrative structure and, frankly, staggering boredom and bizarreness to contend with. But also, at its simplest there is the question of what it is that one is looking for when thrown into the bowels of these huge monstrous machines made of humans and other material-affective substances. To ethnographically grasp the workings of bureaucracy, one needs a hook of some sort. Otherwise, one risks drowning in bureaucratic banality. The hook 
that became patent to Laura Bear and myself, from our separate research in the post-liberalisation Indian state, was that of ideals like 'transparency', 'accountability', 'austerity' or what we came to conceptualise as the 'new public goods' that can open up a new anthropology of bureaucracy (Bear and Mathur 2012). I personally found the perusal of transparency as an ideal that takes on material and affective forms in the state the most effective way to get into the gargantuan developmental Indian state. Following the state's attempts to render itself transparent didn't just demonstrate how and why it was failing to do so effectively but, more importantly, shifted my idea of what the state in practice is; how do we compute failure; and what counts as success for the state itself. The articles in this special issue focus closely on the perusal of the utopic ideals of justice or human rights or the relieving of suffering that the international organisations they are so assiduously studying are deeply invested in. Remaining alive to their contexts, the arguments they have around how ideals get blunted or how utopic projects persevere or perish, each article makes a unique contribution on specifics while also deepening the anthropology of bureaucracy.

\section{Utopianisation}

Utopianism is not, of course, just a methodological hook but also a way of re-imagining what a bureaucracy or an international organisation is about. In this act of reimagining and, particularly, in the concomitant move of shifting away from looking at mere structures or theoretical positions of, for instance, the violence of bureaucracy that a critical move is made by this collection. One of the big gains in the focus on utopianism is to think of process as not just empty and deadening proceduralism but as generative: often of paradoxical results or failed hopes, but as productive of something that moves beyond the inert. In ethnographic engagement to these processes whereby ideals or utopic imaginaries are attempted to be enacted, a host of interesting and surprising facts emerge. For instance, going against the grain of the vast corpus of literature that argues for the depoliticising effects 
of human rights, Babul shows that in the context of Turkey the human rights field was able to withstand co-optation by the liberal governmental framework in Turkey. Even when showing the dark side of bureaucracy such as the masters of disorder in Billaud's case - we glimpse the utopian belief in justice for war victims, albeit grounded in much more prosaic objectives such as the prevention of violations of the law. In other words, despite the stranglehold of audit cultures and the institutional weaknesses enabled by neoliberal projects of austerity or good governance, we don't lose sight of these glimmers of ethical ideals that form the original bedrock of the bureaucracies. To hold onto these ideals and not allow them to be entirely overshadowed by the workings of audit societies or the ravages of late capitalism, these ethnographies are opening up aspects of international organisations that are, in these cynical times, all-too-often dismissed especially by some of the critical literature focused purely on institutions and organisations.

\section{Comparison as written into Ethnography}

This issue is littered with acronyms of a form that are surprisingly recognisable to many of us, including those who don't work on or with international organisations. The recognisability of these acronyms and a vague sense of knowing what these varied institutions are about, brings home their omnipresence in a world that we are now coming to see as connected - through ideas, history, capital, and the ecological breakdown rather than separated out into political units such as the nation-state. Finally, and linked to the nonplace-based origins of the word utopia, what this collection also brings out in sharp relief is the value of comparative work. We see that not all humanitarian organisations are the same and that human rights activism produces starkly different results depending on context. The afterlives of international organisations that might no longer be in existence or the imagined futures of those that are - with their ideals of world justice or alleviation of suffering - linger in the global air, so to say. Much as the IDs I discuss above, there are utopias of different forms within each project and institution. In lieu of dismissing these utopias as 
meaningless or as killed-off by the spread of disenchanted modernity through deadening bureaucratisation - we need to find ways to render them ethnographically visible and to, as Billaud and Cowan assert in their introduction, "recapture the progressive political projects for which bureaucracies were initially established." Progressive and radical political visions and the labour that goes into making them real by bureaucratic action and affect cannot be simply captured through a reference to utopias or an elaboration of founding ideals and moral positions. Neither ought it to be dismissed as killed-off by bureaucratisation. Rather, it is in and through a methodological commitment to the processes - by ethnographically studying what we can perhaps call "the utopianisation of bureaucracy" that their lives, deaths, and afterlives can be vividly brought to the fore.

Bear, Laura, and Nayanika Mathur. 2015. 'Remaking the Public Good: A New Anthropology of Bureaucracy'. The Cambridge Journal of Anthropology 33 (1): 18-34.

Bear, Laura. 2015. Navigating Austerity: Currents of Debt Along a South Asian River. Stanford University Press.

Ghertner, Asher. 2015. Rule By Aesthetics: World-Class City Making in Delhi. Oxford University Press.

Gordin, Michael, Helen Tilley, and Gyan Prakash. 2011. Utopia/Dystopia: Conditions of Historical Possibility. Princeton University Press.

Gupta, Akhil. 2012. Red Tape: Bureaucracy, Structural Violence, and Poverty in India. Duke University Press.

Hull, Matthew S. 2012. Government of Paper: The Materiality of Bureaucracy in Urban Pakistan. University of California Press.

Mathur, Nayanika. 2016. Paper Tiger: Law, Bureaucracy and the Developmental State in Himalayan India. University of Cambridge Press.

Qureshi, Ayaz. 2017. AIDS in Pakistan: Bureaucracy, Public Goods and 'Civil Society'. Palgrave Macmillan. 